\title{
当科に持ける鼻副鼻腔手術の臨床統計
}

\author{
栫 博幸 - 西川 和明 - 喜多村 健 \\ 平出 文久*・森田守
}

\section{Nose and Sinus Surgery Cases at Our Department}

\author{
Hiroyuki Kakoi, Kazuaki Nishikawa, Ken Kitamura and Mamoru Morita \\ (Jichi Medical School) \\ Fumihisa Hiraide \\ (Tokyo Medical College)
}

A statistical study was made on 1502 cases who received surgical treatment for nose or sinus diseases between Apr. 1974 and Dec. 1990. Malignant tumor cases were excluded.

There were 999 males and 503 females, and they were most predominantly in their thirties (312 cases, 20.8\%).

Recently, the number of chronic sinusitis cases was gradually decreasing and the symptom of sinusitis became milder.

Therefore, the number of bilateral curative operation cases was decreasing and that of nasal cavity plastic operation cases, such as deviatomy and endonasal ethmoidectomy, has been increasing.

Polypotomy is a palliative measure but is useful for children and aged people.

Nasal allergy cases were increased in number and some of them had received deviatomy and conchotomy to alleviate nasal obstruction.

Key words: nose and sinus disease, surgical treatment, statistical study

はじめに

昭和 49 年 4 月に自治医科大学附属病院が開院 して以来数多くの手術が施行されてきた. 鼻副 鼻腔に対する手術も，悪性腫瘍の手術を除いて 1562例，1885件を数えるに至った。食生活や生 活環境の変化は, 鼻副鼻腔疾患の病態にも影響 を及ぼし，それに応じて鼻副鼻腔手術の術式や 適応も少しずつ変わってきている. 今回これら の手術症例について, 臨床統計学的な検討を加
えたので報告する。

\section{対 象}

昭和 49 年 4 月から平成 2 年 12 月までの約 17 年 間に, 自治医科大学附属病院耳鼻咽喉科で鼻副 鼻腔に対する手術を行った症例は1562例あった が, 統計学的に比較し易いよ5に, 昭和51年以 後 3 年毎に $5 つ$ 年代に分けて検討した。なお 鼻副鼻腔悪性腫瘍に対する手術症例は除外した. 対象となったのは1502例で，5つの年代別に 
年齢分布括よび性差, 手術例数, 疾患別手術例 数，慢性副鼻腔炎扣よび鼻茸に対する手術の変 化, 鼻中隔弯曲症・慢性肥厚性鼻炎および鼻了 レルギーに対する術式の変化等について検討し た。

\section{結 果}

1）年齢別分布护よび性差（図 1，表 1)

1502例の内訳は男性999例，女性503例で男女 比は1.9：1であった．年齢は1502例中 30 歳代 が312例（20.8\%）と最も多く，40歳代が280例 （18.5），20歳代が264例（17.6\%）と続いてい

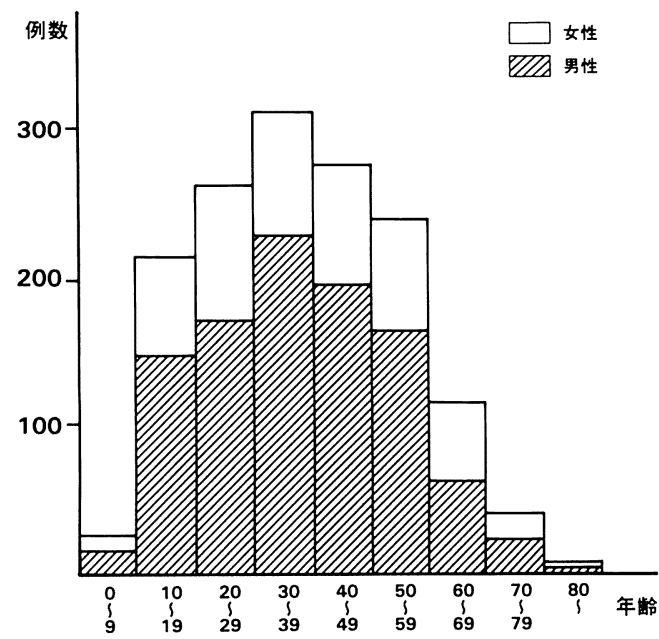

図 1 年龄別分布（昭和51年～平成 2 年）
た. 10歳未満は23例 (1.6\%), 80歳代は 5 例 (0.3 \%）と極めて少なかった．男女別に年齢を検討 すると男性では999例中30歳代が228例 (22.8\%) と最も多かったが，女性では503例中20歳代が 94例（18.7\%）と最も多かったものの，30～50 歳代も 84 例（16.7\%) 86例（17.1\%）とあま り差がなかった。

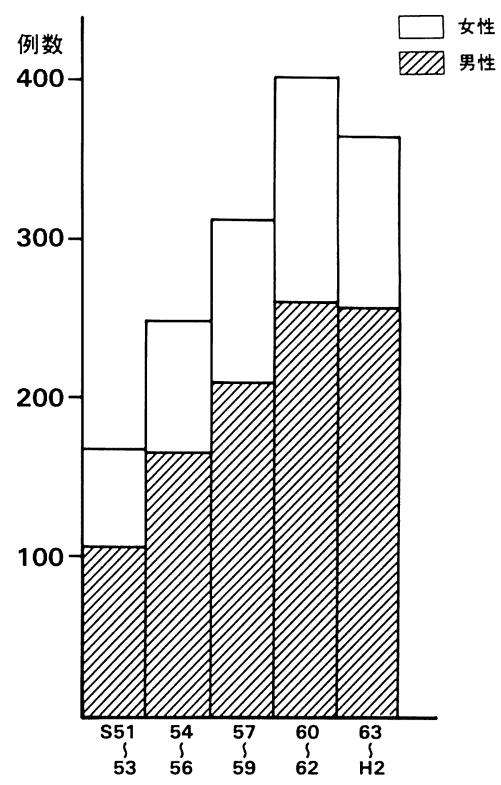

図 2 年代別手術例数

表 1 年代別年龄分布

\begin{tabular}{|c|c|c|c|c|c|c|c|c|c|c|c|c|}
\hline \multirow{2}{*}{ 年 齢 } & \multicolumn{2}{|c|}{ 昭和 $51 \sim 53$} & \multicolumn{2}{|c|}{ 昭和 $54 \sim 56$} & \multicolumn{2}{|c|}{ 昭和 $57 \sim 59$} & \multicolumn{2}{|c|}{ 昭和 $60 \sim 62$} & \multicolumn{2}{|c|}{ 昭和63～平成 2} & \multicolumn{2}{|c|}{ 総 計 } \\
\hline & 男性 & 女性 & 男性 & 女性 & 男性 & 女性 & 男性 & 女性 & 男性 & 女性 & 男性 & 女性 \\
\hline $0 \sim 9$ 歳 & 4例 & 3 & 1 & 5 & 6 & 2 & 1 & & 1 & & 13 & 10 \\
\hline $10 \sim 19$ & 14 & 6 & 24 & 7 & 20 & 13 & 46 & 21 & 41 & 22 & 145 & 69 \\
\hline $20 \sim 29$ & 21 & 17 & 32 & 11 & 29 & 22 & 42 & 23 & 46 & 21 & 170 & 94 \\
\hline $30 \sim 39$ & 23 & 11 & 60 & 18 & 46 & 19 & 52 & 24 & 47 & 12 & 228 & 84 \\
\hline $40 \sim 49$ & 22 & 6 & 31 & 20 & 44 & 13 & 48 & 25 & 51 & 20 & 196 & 84 \\
\hline $50 \sim 59$ & 13 & 13 & 14 & 10 & 47 & 22 & 48 & 22 & 42 & 19 & 164 & 86 \\
\hline $60 \sim 69$ & 4 & 2 & 4 & 8 & 14 & 10 & 16 & 23 & 22 & 12 & 60 & 55 \\
\hline $70 \sim 79$ & 4 & 4 & 2 & 2 & 4 & 4 & 6 & 5 & 5 & 3 & 21 & 18 \\
\hline $80 \sim$ & 1 & 1 & & & & & & 1 & 1 & 1 & 2 & 3 \\
\hline & 106 & 63 & 168 & 81 & 210 & 105 & 259 & 144 & 256 & 110 & 999 & 503 \\
\hline
\end{tabular}


2 ) 年代別手術例数の推移（図 2, 表 1)

手術症例は年々増加傾向を示していたが，昭 和58年に103例と年間100例を越えてからは，昭 和59年139例, 昭和60年147例, 昭和61年141例, 昭和62年125例，昭和63年130例，平成 1 年114 例，平成 2 年 120 例と昭和 60 年をピークとして やや減少傾向にある. 年代別性差については, 前述のように全体としては男女比は約 $2: 1$ で あったが，昭和63年〜平成 2 年では $2.3: 1$ と 男性がより多くなっていた。

3 ) 疾患別手術例数の推移（図 3 )

手術対象となる疾患を大きく, 慢性副鼻腔炎
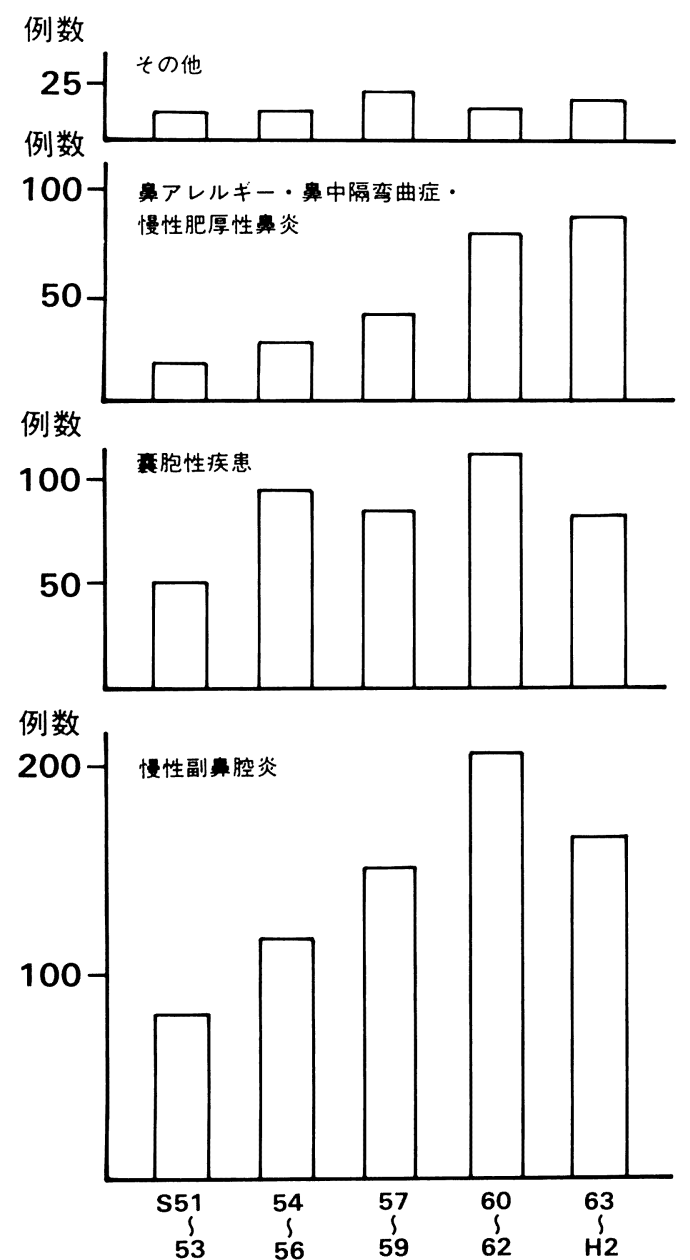

図 3 疾患別手術例数の推移
扣よび鼻茸, 褧胞性疾患, 鼻アレルギー・慢性 肥厚性鼻炎括よび鼻中隔弯曲症，その他の 4 つ に分けてその手術例数を検討した．慢性副鼻腔 炎に対する手術症例は開院当初は年々増加して いたが，昭和63年〜平成 2 年になってやや減少 傾向を示していた。これに代わって，鼻アレル ギー・慢性肥厚性鼻炎扣よび鼻中隔弯曲症に対 する手術例は年々大幅に増加して括り，昭和63 年〜平成 2 年の 3 年間では全体の約 $25 \%$ に達し

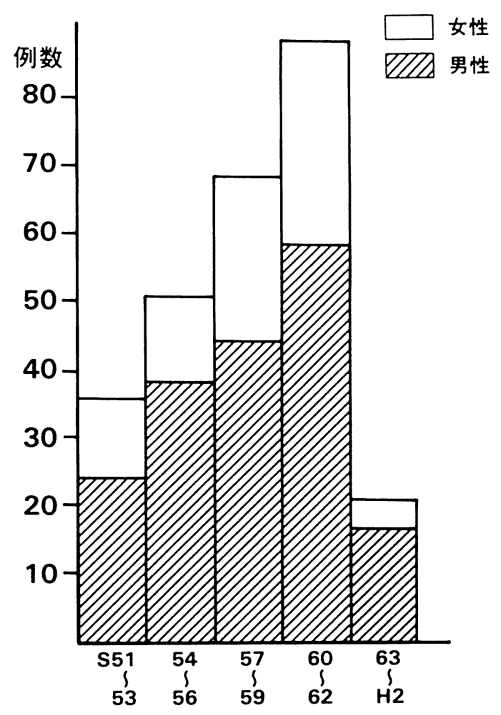

図 4 両側根治手術施行例の年代別推移

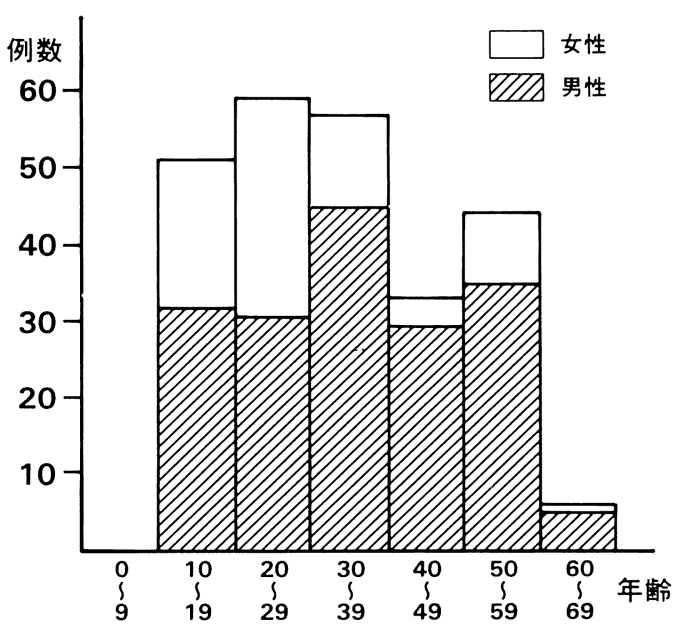

図 5 両側根治手術施行例の年齢分布 
ていた。

4) 根治手術（図 4, 図 5, 図 6 )

慢性副鼻腔炎に対して, 経上顎洞的に上顎洞 と篩骨蜂巣を開放するいわゆる上顎洞篩骨蜂巣 根治手術を両側に行った症例は260例あるが, 昭和60年に行った年間36例をピークとして年々 減少して扣り, 昭和 63 年〜平成 2 年では 3 年間

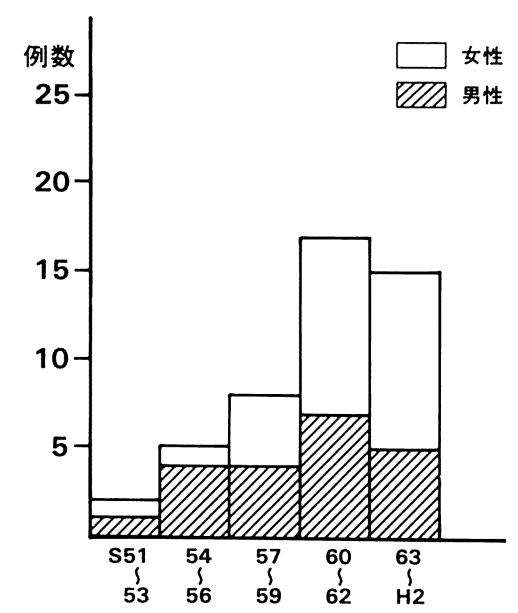

図 6 根治手術の対側に鼻内手術 (十鼻中隔手術) を施行した症例数

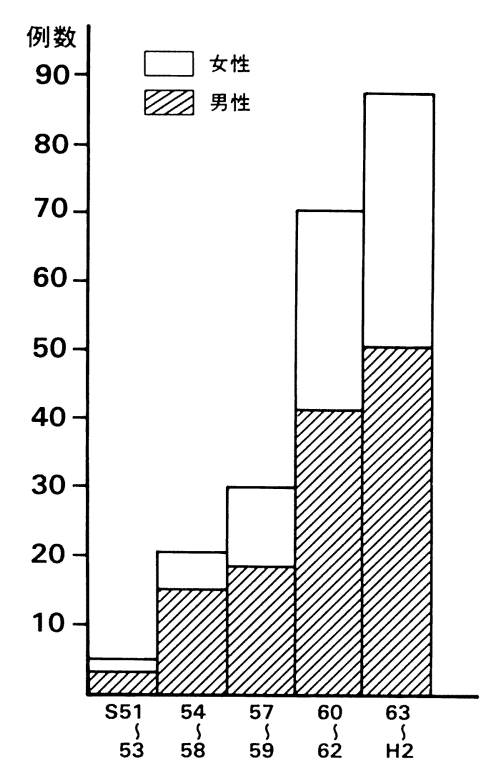

図 7 両側鼻内手術施行例の年代別推移
にわずか 21 例と激減していた，年齢別では10〜 30歳代に多くみられ, 性別は男性177例, 女性 83例で男女比は $2.13: 1$ であった。これに対し て根治手術を 1 側にのみ行い，他側には鼻内手 術, 鼻中隔矯正術あるいは両者併用を行った症 例は, 年々増加傾向にある.

5 ) 鼻内手術（図 7, 図 8)

慢性副鼻腔炎括よび鼻茸の症例に対して, 両 側の篩骨蜂巣を開放するいわゆる鼻内手術を行 った症例は 222 例あり，急増している．昭和63 年〜平成 2 年では 88 例に及んでいたが，この中

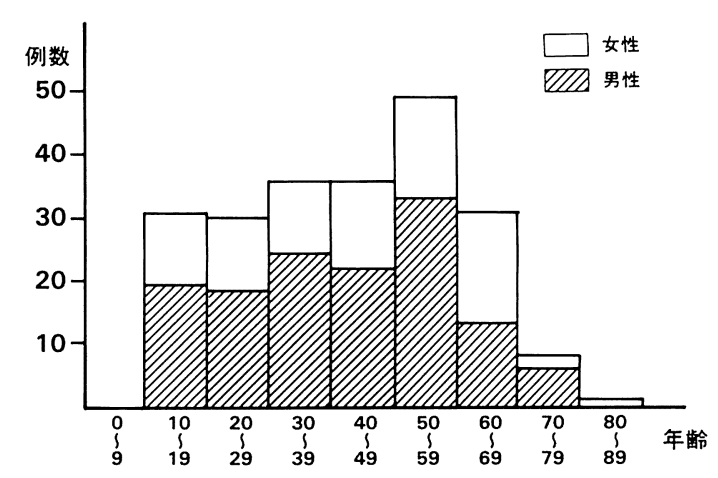

図 8 両側鼻内手術施行例の年㱓分布

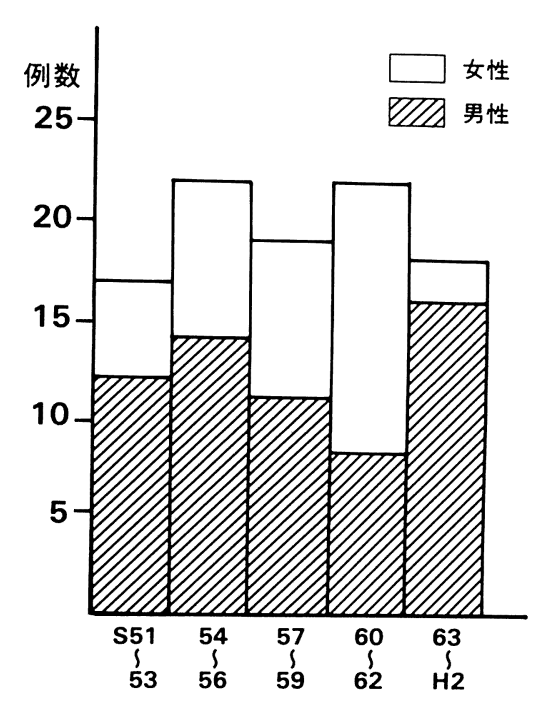

図 9 両側鼻茸切除術施行例の年代別推移 
で鼻中隔矯正術を併せて施行した症例は21例 （24\%）であった．年齢別では，50歳代で49例 と若干多くなっているが，10～60歳代まで平均

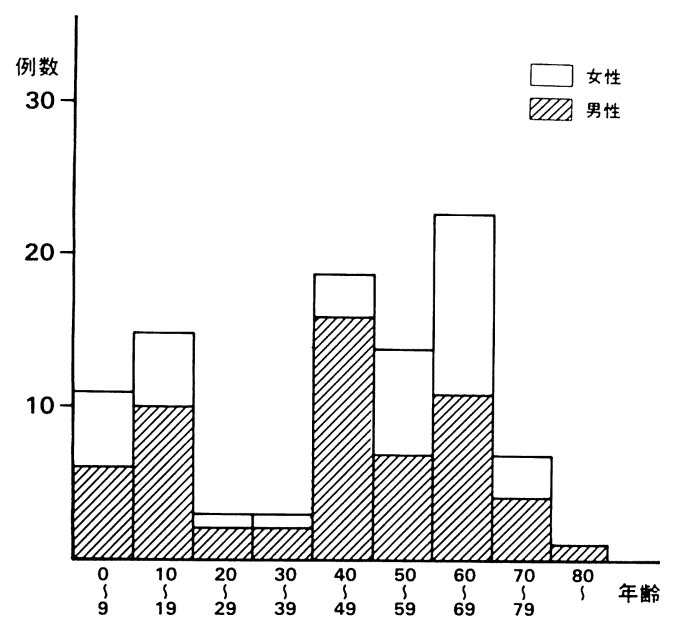

図10 両側鼻茸切除術施行例の年路分布

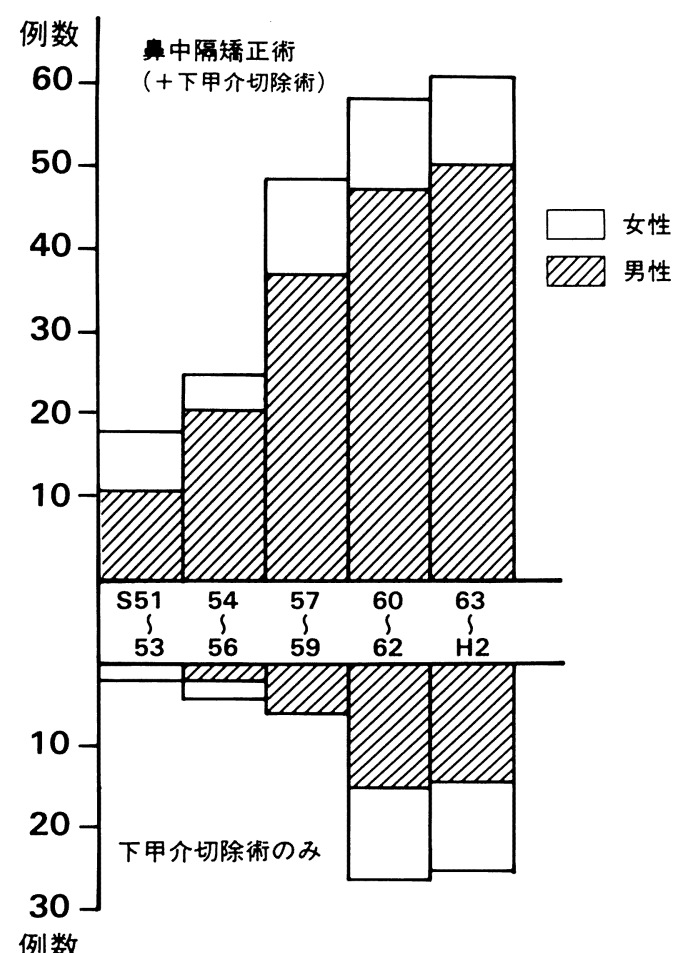

図11 鼻中隔矯正術と下甲介切除術施行例の年代 別推移
しており大きな差は認められなかった。

6 ）鼻咠切除術（図 9, 圀10)

鼻茸のある慢性副鼻腔炎の症例に対して, 鼻 茸切除術のみを行った症例は96例であった。年 代別推移は各 3 年間に 17 22例とほぼ一定して いた．年路分布をみると，60歳代が23例と最も 多く, 次に40歳代19例，10歳代15例となってい た. 20 歳代と 30 歳代はそれぞれ 3 例ときわめて 少なかった。

7 ）鼻中隔矯正術と下甲介切除術 (図11, 図12)

鼻中隔矯正術は，そのほとんどが下甲介切除 術を併施しており，その数は213例にのぼり， 年々増加傾向にあった. 年齢分布は20歳代 92 例 (43.2\%)，10歳代51例（23.9\%）と両者をあわ

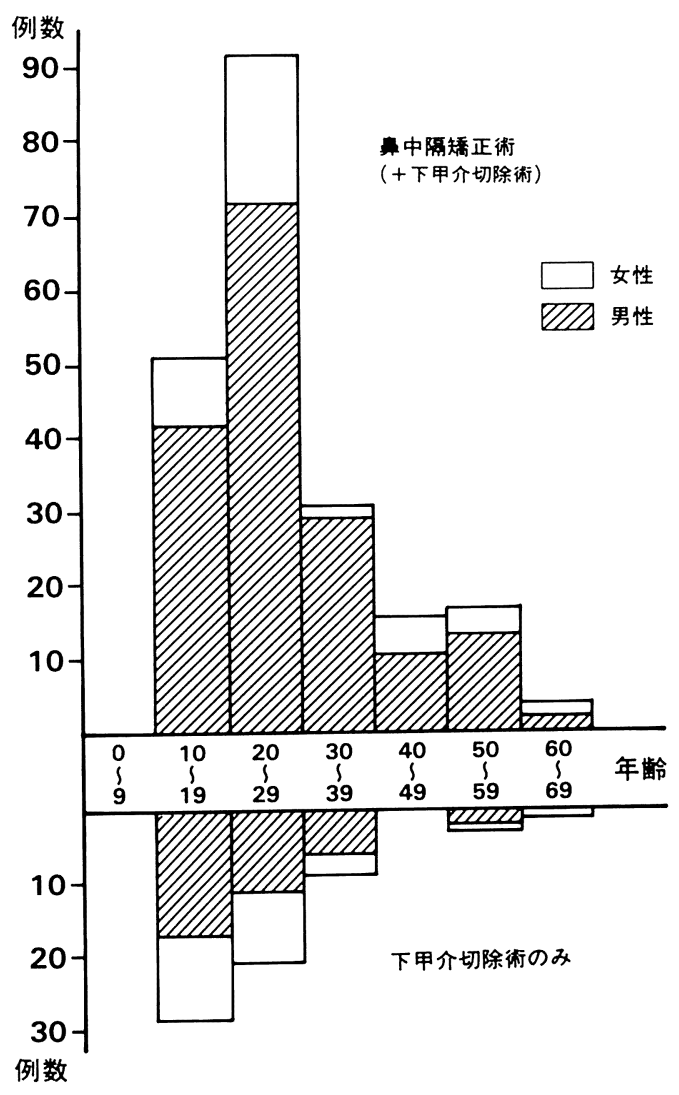

図12 鼻中隔矯正術と下甲介切除術例の年路分布 
せると全体の67\%にあたっていた，性差につい ては男性170例（79.8\%），女性43例（20.2\%） となり, 男女比は 3.95: 1 となった. 下甲介切 除術のみを施行した症例は65例あって，これも 年年増加傾向にあった．年齢分布は10歳代 $(29$ 例，44.6\%)，20歳代 (21例，32.3\%）が多く 全体の $76.9 \%$ 占めていた. 性差については男 性38例 (58.5\%)，女性27例（41.5\%）でわず かに男性に多い傾向にあった。

8 ）その他の手術（表 2)

慢性副鼻腔炎, 鼻アレルギー, 慢性肥厚性鼻 炎, 鼻中隔弯曲症, 術後性上顎襄胞以外の疾患

表 2 手術を要したその他の鼻副鼻腔疾患

\begin{tabular}{|c|c|c|c|}
\hline 疾 患名 & 男性 & 女性 & 計 \\
\hline 鼻前庭製胞 & 4 & 7 & 11 \\
\hline \multicolumn{4}{|l|}{ 歯性慗胞 } \\
\hline 歯根龔胞 & 7 & 3 & 10 \\
\hline 濾胞性歯芽䔩胞 & 1 & & 1 \\
\hline 鼻涙管瀵胞 & 1 & & 1 \\
\hline \multicolumn{4}{|l|}{ 鼻出血 } \\
\hline 粘膜移植 & 3 & 1 & 4 \\
\hline 前篩骨動脈結禁 & 1 & & 1 \\
\hline 鼻中隔穿孔 & 3 & & 3 \\
\hline 鞍鼻 & 1 & & 1 \\
\hline 上顎骨䯣炎 & 1 & & 1 \\
\hline 眼窩蜂窩織炎 & 1 & & 1 \\
\hline \multicolumn{4}{|l|}{ 異物 ～～～～～～～} \\
\hline 上顎洞 & 3 & 1 & 4 \\
\hline 前頭洞 & 2 & & 2 \\
\hline \multicolumn{4}{|l|}{ 外傷 } \\
\hline 鼻骨骨折 & 8 & 5 & 13 \\
\hline 顔面骨折 & 15 & & 15 \\
\hline blow out fructure & (2) & (2) & (4) \\
\hline 頉骨骨折 & 2 & 1 & 3 \\
\hline \multicolumn{4}{|l|}{ 良性腫瘍 } \\
\hline 乳頭腫 & 13 & 9 & 22 \\
\hline 骨腫 & 1 & & 1 \\
\hline 血管腫 & 2 & 1 & 3 \\
\hline 神経鞘腫 & 1 & 1 & 2 \\
\hline 平滑筋腫 & & 1 & 1 \\
\hline 多形性腺腫 & 1 & & 1 \\
\hline 総 計 & 71 & 30 & 101 \\
\hline
\end{tabular}

で手術を施行した症例数を示した．ただし，副 鼻腔霊胞は除いた，総数は101例となるが，鼻 出血に対し鼻中隔粘膜に皮膚を移植した 4 例の らち 1 例は74歳男性の Osler 病であり，36歳鞍 鼻症例に対する腸骨遊離移植例, 56歳の上買骨 骨䯣炎症例に対寸る Denker 手術例, 眼窝内蜂 窩織炎の12歳男児に対する鼻内篩骨蜂巣開放症 例などが含まれていた，鼻骨骨折は一般に外来 で非観血的に整復しているが，観血的整復が必 要な症例や局所麻酔では治療できないような小 児，また全身麻酔を希望する症例では入院させ 全身麻酔下に整復していた. 顔面外傷症例はこ こ数年増加していた．良性腫瘍は総数30例で少 ないが，その中乳頭腫は22例と大多数を占めて いた。これらの腫瘍症例に対する術式は腫瘍存 在部位によって異なるが，上䫇部分切除術 15 例， 荻野式術＋鼻内手術 3 例，上顎部分切除術 + Killian 手術 2 例, 鼻内手術のみ 2 例となっ ていた.

\section{考察}

当院に打ける鼻副鼻腔疾患に対する手術件数 は年々増加し, 昭和58年に年間100例を突破し てからは, 1 年あたり平均約 130 例, 約 150 件の 手術が行われている. 金田ら ${ }^{1)}$, 仲神ら2) が示 しているように，患者の主体は10～50歳代にあ って，特に30歳代にピークがみられる．また男 女比についても男性が多いようである. 当科の データにおいても慢性副鼻腔炎の手術は男性に 多く，特に30歳代に多くなっている．女性では 20〜50歳代まで患者の数は注とんど一定であっ た。

疾患別に手術症例数をみると最後の 3 年間で 慢性副鼻腔炎に対する手術が減少する反面, 鼻 アレルギー・慢性肥厚性鼻炎および鼻中隔弯曲 症に対する手術が特に男性患者で急増している. 田中3) は, 昭和30年代に㧈いて10２0歳代の慢 性副鼻腔炎患者が極めて多く, その後は激減し ているといらデータを発表していることから， この時代10２0歳代であった患者が，約30年経 た今日の $30 〜 40$ 歳代手術患者のピークを形成し 
ているとも考えられる，慢性副鼻腔炎患者が減 少しその症状が軽症化する反面, 鼻アレルギー が増加してきたことに関しては，多くの報告3) があり, 食生活の变化や大気污染による環境の 変化などが原因とされている.ここ $5 \sim 6$ 年は アレルギー患者はほぼ横ばいである4)という報 告があるが，当科においてはまだまだ年々増加 の一途をたどっている. また最近の傾向として， 慢性副鼻腔炎と鼻アレルギーを併発している症 例がしばしば認められるよらになってきた，鼻 アレルギーの治療は薬物治療が主体となるが， やはり鼻閉を強く訴える症例には積極的に手術 をす寸めるべきと考える.

慢性副鼻腔炎症例に対して以前は，その病変 の中心が上㴿洞にあったため, 両側の根治手術 を行らことが多かったが，最近では病変の中心 が篩骨蜂巣と中鼻道に移り, 症状も軽くなって いることから，根治手術を両側に行ら症例は減 少しており，根治手術は症状の重い1側のみに $し て$, 約 1 週間後に, 対側に鼻内篩骨蜂巣開放 術や鼻中隔矯正術あるいはこの両方を併せて行 う傾向にある.両側の鼻内法による手術も激増 している，鼻茸だけを取る手術も，症状をとる だけの姑息的治療ではあるが症例によっては必 要と思われる. 術式の選択には症状, 鼻内所見, 副鼻腔 $\mathrm{X}$ 線所見の他に, 年齢, 職業, 入院期間 などの社会的要因が大きい。例㓪ば，一側根治 手術を行い次週に鼻中隔矯正術, さらに 1 週沶 いて対側根治手術を施行すると約 $4 \sim 5$ 週間の 入院が必要となり, 働き盛りの患者には極めて 困難な状況となる。最近は，病的粘膜を徹底的 に剝離摘出するよりは, 自然口付近の粘膜を清 掃して鼻腔との交通路を確保する isthmus operation を行らことが多いようである. その ためには，鼻腔の整形を目的として，鼻中隔矯 正術により鼻中隔・中鼻道を整形して, 篩骨蜂 单を開放し，上顎洞は膜様部を除去して自然口 を広げる操作が行われる.鼻中隔矯正術と両側 鼻内手術では, $1 \sim 2$ 回の手術で約 $2 \sim 3$ 週間 の入院となり， 1 側に根治手術, 他側に鼻内手
術などを行ら方法でも 2 回の手術, 約 3 週間の 入院で済むことになる．16歳から50歳代までの 患者には, 根治手術や鼻腔整形を主眼とした鼻 内手術をすすめ治療効果に根治性をもとめるこ とが多いが，15歳以下や，60歳以上で心臓病や 高血圧等の合併症のある症例では，鼻咠を切除 して可及的に篩骨蜂巣を開放する姑息的な術式 を選択することが多いようである，高橋5) は小 児副鼻腔炎は自然治癒の可能性があり, 上顎洞 は17〜18歳でほぼ完成するので根治手術はその 以後が良いと言っているが，著者らも基本的に は同様の考えである. しかし, 最近の中学生や 高校生は体格が良いので, 鼻副鼻腔X線所見と その症状，さらには受験やクラブ活動という社 会的要因から手術時期や術式をもっと柔軟性を もって決めてもよいのではないかと考劣る。ま た副鼻腔気管支症候群は副鼻腔炎に対する積極 的治療が原則と考学るが，高齡者には，姑息的 な鼻茸切除と抗生剂のネブライザーや内服，必 要に応じてステロイドの点鼻を併用するなどの 保存療法でもかなり鼻汁や鼻閉を改善させるこ とができると思われる。

大学病院は医育機関でもあるので, 鼻の手術 の基本である副鼻腔根治手術を修練する機会が 年々少なくなるのは問題ではあるが, 社会の変 化に伴い，研修カリキュラムも修正されるべき なのであろら。

$$
\text { まとめ }
$$

1. 過去15年間の鼻副鼻腔手術症例1502例に ついて検討した。

2. 男性999例, 女性503例で男女比は1.9： 1 であった。

3. 年代別にみると 30 歳代が 312 例と最も多 く全体の $20.8 \%$ であった.

4.ここ数年は年間約 130 症例に対して約 150 件の手術が施行されている.

5. 慢性副鼻腔炎の減少と軽症化に伴い, 両 側根治手術例も減少し, 鼻中隔矯正術や鼻内手 術が主流となってきた。

6. 鼻茸切除術は姑息的治療ではあるが, 症 
例によっては選択すべき治療である。

7. 鼻アレルギーの増加とともに, 鼻中隔矯 正術や下甲介切除術が増加してきた。

\section{文献}

1）金田宏和, 鶴田至宏, 田中 治, 他 : 慢性副鼻 腔炎根治術施行症例の臨床統計. 耳鼻臨床 補 $37: 114 \sim 120,1990$.

2) 仲神みつこ, 藤林慶子, 堀 瑞代, 他: 当科に 扣ける最近 5 年間の入院患者の統計的観察. 耳 鼻臨床 78 増 $2: 1334 \sim 1340,1985$.
3）田中克彦：慢性副鼻腔炎の疫学的背景. 1 年代 推移について. 鼻副鼻腔 $19: 22 \sim 23,1980$.

4) 井上敦子, 松永 喬, 芦田恒雄, 他: 当科 5 年 間の鼻アレルギー患者受診動態の臨床統計.耳 鼻臨床 補37：156〜160, 1990.

5）高橋 良 : 慢性副鼻腔炎の自然的変動とくにそ の不安定期について. 耳展 $9: 367 \sim 381,1966$.

$$
\left(\begin{array}{c}
\text { 別刷請求先 : 栯 博幸 } \\
\overline{\mathbf{T}} 329-04 \\
\text { 栃木県河内郡南河内町 } \\
\text { 薬師寺3311-1 } \\
\text { 自治医科大学耳鼻咽搌科学教室 }
\end{array}\right)
$$

